\title{
Christian consolation and theology's task today
}

\author{
Rebekah Lamb
}

Dr Rebekah Lamb is a lecturer in theology and the arts at the University of St Andrews.

In recent years the 'most popular' verse on the Bible app YouVersion (which has been installed by over 455 million 'unique users') ${ }^{1}$ has been John 3:16 or Jeremiah 29:11. ${ }^{2}$ However, following on from the emergence of the Covid-19 pandemic, Isaiah 41:10 became the most searched, read, and bookmarked verse on YouVersion in $2020 .^{3}$ This text from Isaiah offers Israel (and other distant lands) much-needed consolation, relaying God's message of care for his creation:

So do not fear, for I am with you; do not be dismayed for I am your God.

I will strengthen you and help you;

I will uphold you with my righteous right hand.

The broader context for this chapter is helpful to remember here. Given headings such as "The Helper of Israel" (NIV) or "God's Assurance to Israel" (GNB), Chapter 41 lists examples of the provident care God had shown throughout history. However, it not only explores how such care is operative in instances of joy and hope; it also highlights the degree to which creation is drawn closer to God through experiences of sorrow and suffering. War, death, disease, hunger, fear, anxiety, and poverty are some of the many sorrows Isaiah 41 catalogues as instances which reveal to us the inner-depth dimension of divine mercy and God's concern for his creation. In other words, Chapter 41 does not offer consolation by ignoring suffering and pain. Rather, it shows that God is within and beyond it. In this way, the Book of Isaiah communicates the unfolding of salvation 


\section{Christian consolation and theology's task today}

history, playing a key role in outlining the Judeo-Christian theology of consolation as one rooted in God's promise that he will make 'all things new' through his 'redemptive plan for all history'. ${ }^{4}$

During our current times it has often been difficult for many to reconcile the concept of a provident God with the sufferings and uncertainties the pandemic has caused. However, as the most recent YouVersion stats remind us, the search for meaning today often brings people back to the messages of consolation offered in the Old and New Testaments. In this article I propose that the unique understanding of consolation (which is cruciform in shape) made available to us in

Christianity can serve as a way to navigate the burdens we are facing today. The pandemic has radically reminded us of the fact of our mortality, removing many of the distractions which can keep this existential reality at bay. In so doing, it has dispelled the illusion that we are self-sufficient, able to make and supply meaning in life solely on our own terms and according to our own understanding. While this may cause an understandable crisis in our sense of identity it also opens up to us the reality of our dependency, our creatureliness, the fact that life is a gift (over which we have only so much control). It is precisely at the crossroad (or crucible) between providence on the one hand and immense human devastation on the other that Christ stands. The Christian theology of consolation does not skirt around the issue of suffering. Rather, it enters into the depths of the abyss of human misery, finding a renewed sense of hope and meaning by seeking out the presence of the risen Christ who endured the challenge of the cross, transvaluating its meaning. ${ }^{5}$

This is why, as Joseph Ratzinger notes, the believing theologian is presented with an important task in our times. This task (which is also a challenge) is to communicate that God is, as John Henry Newman puts it so helpfully, not a notional construct but rather a living, personal God. ${ }^{6}$ It is only this kind of personal witness and engagement that can reach into, meet, and speak to the real issues and difficulties we are facing today. As Ratzinger notes, in "The Feeling of Things, the Contemplation of Beauty", the person who believes

in the God who manifested himself, precisely in the altered appearance of Christ crucified as love "to the end" (Jn 13,1) [...] learns that the beauty of truth embraces offence, pain, and even the 


\section{Christian consolation and theology's task today}

dark mystery of death, and that this can only be found in accepting suffering, not in ignoring it.. ${ }^{7}$

One of the crucial challenges (and also opportunities) for theologians and theology in the face of the pandemic is to discern and communicate the 'beauty of truth' and the reality of hope to society so as to help us remember that loss, fear, and suffering do not have the last word. As importantly, the task of Christian theology is also to show that, as with the crucifixion, the suffering in our lives can be transformed into a means of greater unity with Christ, the wounded healer. If we are to follow the conviction of Isaiah and the traditions of the Christian theology of redemption, we see that it is precisely in Christ as the wounded healer that we find an irreplaceable consolation for our current times.

Understandably, a wounded healer may sound like a strange consolation for us, and an especially counter-cultural one. We live in an era of painkillers, sedatives, and a wholly unprecedented level of consumable comforts - at least throughout much of the Western world. Many of these comforts are gifts but if viewed as ends in themselves they can come to distract us from 'the one thing needful', in the end. In the face of the suffering brought on by the pandemic and related factors, Christ's status as wounder healer is one which especially speaks to the depths of our need and the heights of our longing for renewed and fuller life. Meditating on the nature of the Christian imagination, Erich Przywara proposes that it is in the cruciform vision of the world that Christianity offers an access to hope that can withstand human suffering. Indeed, he reminds us that the witness of Christian art, throughout church history, upholds the cross as a sign of hope, contradicting the various fears we have endured throughout the course of history. In this way, he concludes that "the "scandal of the folly of the Cross" [which births resurrection] appears as the origin, measure, and defining goal of Christian sacred art' and of the Christian worldview itself. ${ }^{8}$ Indeed, it is no surprise that much of the world's most profoundly religious art has been forged in the crucible of suffering - this is especially true of Christian art or art that engages with the Christian message as revealed in Scripture and lived experience. As just a few examples, Fyodor Dostoevsky admitted that his novels were a 'Hosannah' spoken out of 'a furnace of doubt', ${ }^{9}$ and Toni Morrison proposes, in Mouth Full of Blood, that the deepest, artistic reckoning with 


\section{Christian consolation and theology's task today}

reality 'gains its strength, beauty, and unassailability from biblical or holy texts.' 10

Given all this, it is no surprise that during this time of the pandemic people have turned to Scripture for consolation and hope. It is theology's task today to help support those searching for meaning in the face of their suffering, offering them a horizon of hope that extends beyond the goods and limitations of technology, science, and even the most essential of material needs. While our need for technology and scientific advancements to curtail the damage and spread of Covid-19 is urgent, the need to nourish our souls is just as pressing. As other contributors to this special issue discuss, the current crisis reminds us of our fragility, our need for human connection in incarnational forms, such as prayer, the arts, face-toface encounter, and liturgical forms of worship.

These observations have been especially put forward in Julián Carrón's recent pastoral open access book, Reawakening Our Humanity: Reflections in a Dizzying Time, which focuses on how our current crisis reminds us of our creatureliness (especially our mortality), and our need for divine mercy (which is the heart of the message of Christian consolation). Especially in the Western context, he reminds us that

The situation we are experiencing has made us aware that, for a number of years, we have lived, in some sense, as if we were in a bubble that protected us from the blows of life. And so, we went about our lives distracted, pretending that we could control everything. The circumstances, however, spoiled our plans and gave us a rude awakening, telling us to take ourselves seriously and rethink our situation in life. ${ }^{11}$

Carrón goes on to contextualize this observation by noting that our vulnerability, our creatureliness, is not a new reality but, rather, something that illness and suffering return to our attention. ${ }^{12}$

I wish to conclude this reflection on the task of theology in the time of the Covid-19 pandemic by homing in on a key aspect of Carrón's theology of consolation as found in Reawakening Our Humanity. In so doing, we will also implicitly return to the message of Isaiah 41, which affirms the presence of providence within the suffering of his creation. As noted above, one of the central ideas Carrón presents to us for our reflection is 


\section{Christian consolation and theology's task today}

the reality of human fragility, and the degree to which this fragility is only adequately acknowledged, and then transformed, through an initiation into the 'science of the cross' (to borrow one of Edith Stein's most famous phrases).$^{13}$ Specifically, he proposes that the trials of this time encourage us to live out the words of the Gospel in a way that is not merely conceptual or propositional but lived, felt, and real. He closes his book with the observation that embracing the difficulties of this time, and persevering through them, enables us to transform our daily lives into acts of faith and praise. In so doing, we enter into and share in Paul's proclamation of faith and hope, expressed in Romans 8:35-39, which holds that the trials of the Church cannot 'separate us from the love of Christ'; rather, they draw us more deeply into the heart of divine mercy. ${ }^{14}$ In communicating the cruciform pattern of Christian consolation, Christian theologians can make an invaluable contribution to our perseverance in these difficult times.

\section{Notes}

1 Life.Church, "YouVersion", https://www.youversion.com/the-bibleapp/

2 Bishop Robert Barron and Brandon Vogt, hosts, "WOF 267: 'Do Not Be Afraid",, Word on Fire (podcast), January 20, 2021, https://www.wordonfireshow.com/episode267/. I am grateful to Michael D. Hurley for highlighting the YouVersion statistics for 2020 in the first instance.

3 Ibid.

4 Orlando R. Barone, et al., General Commentary on "The Book of Isaiah", in The New Catholic Study Bible (New York: Catholic Bible Press, 1985), $569 \mathrm{f}$.

5 For further discussion on the Christian theology of consolation see John Paul II's Salvifici doloris, encyclical letter, Vatican website, 11 February 1984, http://www.vatican.va/content/john-paul-ii/en/apost_ letters/1984/ documents/hf_jp-ii_apl_11021984_salvifici-doloris.html

6 John Henry Newman, Essay in Aid of a Grammar of Assent (London; New York: Longmans, Green \& Co., 1903), 42-98.

7 Joseph Ratzinger, "The Feeling of Things, the Contemplation of Beauty", Vatican website, 24-30 August 2002, http://www.vatican.va/ 


\section{Christian consolation and theology's task today}

roman_curia/congregations/cfaith/documents/rc_con_cfaith_doc_200 20824_ratzinger-cl-rimini_en.html

8 Erich Pryzwara. "Beautiful, Sacred Christian", in Analogia Entis: Metaphysics, Original Structure, and Universal Rhythm, trans. John R. Betz and David Bentley Hart (Grand Rapids, Mich.: William B. Eerdmans, 2014), 554. I am grateful to Christopher Wojtulewicz for introducing me to Pryzwara's contributions to theological aesthetics.

9 Avril Pyman, "Dostoevsky in the Prism of the Orthodox Semiosphere", in Dostoevsky and the Christian Tradition, eds. George Pattison and Diane Oenning Thompson (Cambridge: Cambridge University Press, 2001), $103 \mathrm{f}$.

10 Toni Morrison, "God's Language", in Mouth Full of Blood: Essays, Speeches, Meditations (Vintage Digital, 2019), 222.

11 Julián Carrón, Reawakening Our Humanity: Reflections in a Dizzying Time, ed. Alberto Savorana (Milan: Communion and Liberation, 2020), $9 \mathrm{f}$.

12 Ibid., 18.

13 See Edith Stein's The Science of the Cross, eds. L. Gelber and Romaeus Leuven, trans. Josephine Koeppel (Washington DC: ICS Publications, 2003).

14 Carrón, Reawakening Our Humanity, 68 f. 